\title{
IRENO ANTÔNIO BERTICELLI: TRAJETORIA NA VIDA E NA ACADEMIA
}

\author{
IRENO ANTÔNIO BERTICELLI: LIFE AND ACADEMIC JOURNEY \\ IRENO ANTÔNIO BERTICELLI: TRAYECTORIA EN LA VIDA Y EN LA ACADEMIA
}

Ireno Antônio Berticelli*

ibertice@unochapeco.edu.br

RESUMO: Neste texto procuro contemplar alguns aspectos e episódios da minha história de vida, em especial, a trajetória da vida acadêmica. Assim, na escritura deste bosquejo de biografia não serei sistemático, nem saberia sê-lo. Farei o tempo progredir ora para diante, ora para trás, tentando dar conta de tantas lembranças e episódios vividos no limiar dessa trajetória. Desta forma, na escritura deste bosquejo de minha biografia deixarei que os sentimentos e as memórias tomem conta da difícil, mas necessária tarefa de falar sobre mim mesmo, das origens familiares, das incursões na vida acadêmica, enfim da construção da vida no passado e do presente.

Palavras-chave: Ireno Antônio Berticelli. Biografia. Trajetória na vida. Trajetória na academia.

ABSTRACT: In this text I attempt to contemplate some facets and episodes of the story of my life, specially the trajectory of academic life. So, along the production of this draft of biography I don't pretend to be systematic, and I would not know to be it. I'll make the time progress sometimes forwards and sometimes backwards, attempting to account for so many remembrances and experienced episodes at the threashold of that trajectory. So, in the writing of the draft of my biography I alow that the feelings and remembrances take care of the difficult but necessary task of speaking about myself, about the origins of my family and about the incursions in the academic life, finally, about the construction of life in the past and in the present time.

Keywords: Ireno Antônio Berticelli. Biografia. Trajectory in the life and in the academy.

RESUMEN: En este texto contemplo algunos aspectos y episodios de mi historia de vida, especialmente el camino de la vida académica. Así, en la escritura de este resumen no seré sistemático ni lo sabría ser. Haré el tiempo avanzar a veces hacia delante, a veces hacia atrás, tratando de dar cuenta de tantos recuerdos y episodios vividos en el umbral de esa trayectoria. De esta manera, en la escritura de este bosquejo de mi biografía dejaré que los sentimientos y las memorias se encarguen de la difícil, pero necesaria tarea de hablar sobre mi mismo, de las orígenes familiares, de las incursiones en la vida académica, en fin, de la construcción de la vida en el pasado y en el presente.

Palabras clave: Ireno Antônio Berticelli. Biografía. Trayectoria en la vida y en la academia. 


\footnotetext{
* Doutorado em Educação pela Universidade Federal do Rio Grande do Sul (2000). Atualmente é professor titular da Universidade Comunitária da Região de Chapecó no Programa de Pós-Graduação Stricto Sensu em Educação (PPGE) da Unochapecó.
}

Na escritura deste bosquejo de biografia não serei sistemático. Nem saberia sê-lo. Farei o tempo progredir ora para diante, ora para trás. Deixarei os sentimentos e as memórias ir tomando conta de minha tarefa.

Nasci na assim chamada Linha Esperancinha, em Aratiba (RS), pequena cidade da região do alto Uruguai gaúcho, numa terça-feira, 4 de agosto de 1942. Meus pais, Alberto Berticelli e Vitoria Rebellato Berticelli haviam migrado de Pouso Novo (RS), para esta região, em 1939. Durante muitos anos eu ignorava o ano que foram habitar na Esperancinha. Tardiamente, minha memória recuperou a lembrança de que meus pais se reportavam em língua italiana, referindo-se ao ano de sua migração como sendo "neltrenta nove", ou seja, no ano de 1939. A região de Pouso Novo (RS), especificamente o lugarejo denominado Forqueta (mesmo nome do rio que por aí passa) era extremamente montanhosa. A agricultura era de dificílima prática aí, e meus pais eram agricultores. A tradicional carroça usada por todo mundo, sobre duas ou sobre quatro rodas, era inutilizável aí: somente a assim dita zorra (uma grande forquilha de madeira assoalhada) era viável. Assim é que os agricultores denominavam esse primitivíssimo "veículo". Pois se consultarmos o dicionário, não encontraremos esta palavra com este sentido, mas era assim que a denominavam os agricultores.

A propósito da migração de boa parte da família Berticelli para Aratiba, contava meu pai que o tio José, irmão mais velho da família é que tomou a frente de buscar um novo lugar para se estabelecer com alguns de seus irmãos e primos. Escolheu Aratiba e, de retorno de sua viagem exploratória, entusiasmado, dizia aos familiares, num complicado dialeto bergamasco que "Là no ghènhàunpredoli", ou seja: "Lá não há uma só pedrinha", referindo-se à boa qualidade da terra, em contraste com as terras da Forqueta, extremamente montanhosas e extremamente pedregosas. Mas, na verdade eram apenas muito montanhosas e muito pedregosas, tal como, em geral, é a região do alto Uruguai gaúcho. A coisa virou piada, quando os migrantes conheceram as novas terras (Aratiba). Diziam ao meu tio José: "No ghègna um predoli, maghè i predolù" (Não há nenhuma pedrinha. Há só as pedras grandes”.

Assim, até os 11 anos vivi no seio da família juntamente com cinco irmãos e duas irmãs. Aliás, estando ainda junto aos meus, casaram-se um irmão e duas irmãs.

Vivi minha infância e parte da meninice sob a Era Vargas. Nunca me esquecerei de uma tarde chuvosa, andando por uma estradinha vicinal que dava em nossa casa, a assim chamada estrada do Paloma, pois levava a esse lugarejo, quando um automóvel passou por mim e por meu irmão Benjamim (mais jovem que eu um ano e um mês), e de dentro do qual alguém jogou um punhado de papeis. Meu irmão com 7 e eu com 8 anos, corremos a ajuntá-los, até porque papéis, em nossa infância, eram pouco abundantes. Era a propaganda da campanha de Getúlio 
Dornelles Vargas, onde se lia: "Ele voltará". Quem diria que, 55 anos depois, eu escreveria um trabalho acadêmico para o curso de doutoramento, com o título: "Ele voltará" ou: "as formulações irremediavelmente equívocas na análise do discurso", depois de ler, no jornal Zero Hora, o histórico desta frase proferida num discurso, por João Goulart, o Jango. Em 1950 Getúlio se elegeu com larga margem de votos.

Pois bem, minha infância transcorreu com muito carinho dos pais e dos irmãos. Muito cedo aprendíamos a trabalhar. Como filhos de colonos (com o sentido de "agricultores"), aprendíamos muitíssimo cedo a trabalhar. Lembro-me que bem antes de começar a frequentar a escola, levantava sempre à luz das estrelas, fosse no inverno, fosse no verão. Na cultura daqueles tempos, acordar com o "sol na cara”, como se dizia, era a máxima vergonha. $\mathrm{O}$ trabalho marcou profundamente a cultura dos imigrantes de que descendo, os italianos (bem como os demais imigrantes). Aliás, tanto meus avós paternos (Berticelli), quanto os maternos (Rebellato) vieram da Itália. Consegui recuperar cópia do "Passaporto" (Passaporte) apenas de meus avós Rebellato. Aportaram no Brasil no início de 1888. Meu bisavô Rebelatto trouxe meu avô da Itália com 6 anos. De meus avós Berticelli tenho a informação de que ele, Giovanni Battista Berticelli, nasceu em Vailate, Bergamo; e ela, Francesca Balconi, nasceu em Rodigo, Mantova.

Meus avós maternos se estabeleceram em Alfredo Chaves (RS), hoje Veranópolis (RS). E os avós Berticelli se estabeleceram na então denominada Colônia Dona Isabel, hoje, Bento Gonçalves, como agricultores.

Sofri alguns atrasos em minha formação escolar. Como se permitia a entrada para a escola somente com 8 anos completos, e meu aniversário é em agosto, tive que esperar o ano seguinte. Assim, entrei para a escola primária com 8 anos e meio, em 1951. Era a Escola Municipal Belo Horizonte, situada a uns $5 \mathrm{~km}$ de nossa casa, na Linha Bem-te-vi, bem próximo à Hidrelétrica de Itá. A escola e a capela de Bem-te-vi surgiram antes que a escola de nossa Linha Esperancinha. Por isto é que meu pai se tornou "sócio" da comunidade do Bem-te-vi e não da Linha Esperancinha. Assim, a família frequentava a Capela do Bem-te-vi e nós estudávamos na Escola Belo Horizonte.

Os tempos eram outros. A escola, que era multisseriada, atendendo cinco turmas que iam do $1 .^{\circ}$ ao $5 .^{\circ}$ ano, era presidida por uma única professora cuja formação havia sido adquirida de outra professora leiga tal como ela. $\mathrm{E}$ estudei na Escola Belo Horizonte até a $3^{\mathrm{a}}$ série. Foi quando passou por aí o Frei Armindo de Oliveira, franciscano da Província Franciscana da Imaculada Conceição do Brasil (que se estendia do Estado do Espírito Santo ao Rio Grande do Sul), que era "procurador de vocações".

Assim, numa manhã, lá por novembro ou início de dezembro, a nossa professora falou sobre a vocação sacerdotal e fez a pergunta: "Quem de vocês quer ser padre?". 
Pois é. Curiosamente, apesar de meus pais serem de profunda fé religiosa católica, nossa casa não era frequentada por padres ou raramente isto acontecia. Mas, naquela manhã, não sei por que inspiração extemporânea e totalmente fora de contexto, eu respondi afirmativamente, levantando o braço, tal alguns outros poucos colegas. Pronto! Começava uma longa história. A professora instou que o pai dos que queriam entrar para o seminário franciscano se apresentasse ao Frei Armindo, no dia seguinte. E assim aconteceu. Meu pai e eu fomos até a capela da Linha Bem-te-vi e nos apresentamos ao frade.

Ele fez uma série de perguntas a meu pai. E logo foi anotando várias coisas: nome de meu pai, meu nome etc., não demorando a passar a listinha para o enxoval a ser providenciado e tudo o mais. Não consigo, hoje, encontrar o que me motivou a tomar aquela decisão infantil. O clero não ficava próximo da vida de nossa família. A igreja matriz de nossa comunidade ficava a $15 \mathrm{~km}$ de distância e só se dispunha de montarias para deslocamento até lá. Não possuindo, até 1959, nenhum veículo motorizado e levando em conta também o relevo difícil da região, penso que, até então, teria ido raras vezes até Aratiba, a sede paroquial.

Meu irmão Benjamim, pouco mais jovem que eu, não pensava em ir para o seminário. Mas quando se deu conta de que eu iria mesmo, aligeirou-se a prontificar-se para me acompanhar e, de fato, ingressamos para o Seminário Seráfico São João Batista, em Luzerna (SC), em fevereiro de 1954. Tudo era uma imensa e misteriosa novidade:

Fomos levados pelo pároco local, Frei João Maria Vianei, de Jeep, para Erechim, juntamente com um segundo primo, um filho de um vizinho e mais alguns meninos de Volta Fechada, um lugarejo de então. Em Erechim, tomamos café num hotel, coisa que nunca havíamos visto. Salvo engano, embarcamos no trem às $7 \mathrm{~h}$. Era tudo um quase assombro pelo desconhecido, para um menino (penso que para os outros igualmente), que nunca havia visto nada daquilo: hotel, trem... até a proximidade de Frei João Maria Vianei, o pároco que nos acompanhou. Para nós, que até aí só andáramos montados a cavalo e de carroça de boi, o trem parecia quase voar, tamanha a velocidade. Calcule-se: saía pelas $7 \mathrm{~h}$ da manhã para chegar em Luzerna à $1 \mathrm{~h}$ da madrugada.18 horas de viagem, de Erechim a Luzerna (SC), que fica próxima a Joaçaba (SC).

Aos 11 anos mergulhei num mundo absolutamente estranho. Do aconchego de uma família de colonos, via-me projetado para uma distância que, para a época, era como se fora infinitamente grande. Assim é que nos 17 anos que se seguiram, de minha formação (conclusão do primário, ginásio, clássico, noviciado, graduação em filosofia, graduação em teologia), recebi uma única visita dos pais, na entrada do noviciado, em Rodeio (SC), em 1965 e uma única visita de um tio, em 1966, no início do curso de filosofia, em Curitiba (PR). 
Bem, é difícil que sempre haja apenas "contras”. Há "prós" também. Sempre. Assim, gostaria de destacar que minha formação, que foi uma verdadeira peregrinação por diferentes lugares, foi um tesouro encontrado. Ao entrar em Luzerna, em 1954, eu havia cursado na escolinha primária do Bem-te-vi as primeiras 3 séries. Concluí o primário em Luzerna, em 1956, com uma reprovação em matemática. Não quero justificar nada, mas já vou adiantando que reprovaria mais uma vez, dada a fragilidade da minha formação escolar em escola multisseriada, sempre presidida por uma única professora absolutamente leiga, ou seja, formada por outra única professora leiga. E os franciscanos, de forte influência alemã, pois a Província da Imaculada Conceição do Brasil, após ser quase totalmente dizimada por Pombal (sobrou um único irmão franciscano), foi restaurada por frades alemães, mantinham um elevado grau de exigência em nossa formação. Assim, levei alguns anos para me recompor das perdas iniciais. Tendo reprovado mais uma vez em latim, no primeiro ano do ginásio, foi apenas no $4 .^{\circ}$ ano ginasial que comecei a ganhar estatura no processo de aprendizagem.

Qual o grande "pró" que entendo foi a meu favor, em todo o percurso da formação do seminário menor (fundamental e médio, na linguagem de hoje) ao seminário maior (filosofia e teologia)? Sem sombra de dúvida foi ter estudado em Luzerna (SC), depois em Rio Negro (PR), a seguir, por seis anos em Agudos (SP) - do segundo ano ginasial ao terceiro ano do clássico. Isto me transferiu um capital cultural inestimável. Em Luzerna, os seminaristas apresentavam uma cultura bastante homogênea, havendo apenas leve diferença entre os que provinham da cidade e dos que provinham da colônia (uso esta expressão corrente até hoje). Chegando em Rio Negro, a diversidade cultural se acentuava e muito. Dava-se, aí, o encontro das turmas que vinham de Luzerna com as que vinham de Rodeio (SC), do vale do Itajaí (Rodeio, Blumenau, Ascurra, Benedito Novo... e de várias localidades da vale). A diferença começava pelo dialeto italiano usado nas famílias de origem. E o sotaque do português também diferia bastante. $\mathrm{O}$ vestuário era diverso. Nós, vindos do alto Uruguai gaúcho e catarinense, do vale do Rio do Peixe, nos vestíamos muito à semelhança dos "colonos". Já os estudantes que provinham daquela outra região, muitos deles eram mais sofisticados no vestir.

De Rio Negro (PR), seguíamos para Agudos (SP), na região de Bauru (SP). Bem, aqui as águas culturais se misturavam num mosaico ainda mais colorido. Lá estávamos nós, já um tanto aculturados com os estudantes provenientes do vale do Itajaí e, então, encontraríamos os estudantes vindos de grandes centros urbanos: de São Paulo, de Santos, do Rio de Janeiro. Eles já conheciam televisão e muitas coisas das grandes cidades.

A convivência inicial com as culturas fortemente urbanas não foi fácil, por um bom tempo. Os paulistas e 
cariocas eram urbanos. Vestiam-se com muito mais esmero. Calçavam com mais classe. Falavam um português sem influência italiana e alemã ou, até polonesa. Desta forma, sofríamos muito com as gozações deles. Nossos erres que soavam "ere" e outros sotaques resultantes de nossa descendência eram motivo de chacota constante. Os grupos se formavam pela proveniência dos sulistas e dos urbanos. Não era raro os paulistas, unidos aos cariocas, ao verem um sulista vindo pelos imensos corredores do Seminário Santo Antônio, de Agudos (SP) - uma magnífica arquitetura neocolonial - e formarem uma espécie de "corredor polonês" e quando o gaúcho ou o "catarina", como chamavam os catarinenses, passava por entre as duas fileiras de seminaristas displicentemente aí postados, como se nada quisessem, se voltavam para o centro do corredor e enquanto um dizia: "Lá vem o carinho" (corruptela de "carrinho") e aplaudiam fragorosamente o infeliz transeunte, mais rubro que pimentão, de vergonha. As brigas por motivos de buling. O modo de brigar dos alunos provenientes dos grandes centros era muito mais sutil, muito mais perigoso e insidioso.

Decorridos vários meses, quase um ano, verificava-se um interessante fenômeno, e este é que tem sido um dos grandes "prós" de minha vida: as culturas diferentes se encontravam e a hostilidade e rejeição se transformavam em admiração mútua. Nós, do Sul, admirávamos a cultura urbana e mais refinada dos paulistas, dos santistas e cariocas. E eles admiravam sinceramente nossa pertinácia, disciplina mental etc. Havia um significativo ganho para ambas as partes. Agudos foi um período de seis anos que, para minha formação, foi a descoberta que o mundo era bem maior do que eu pensava. Os professores, todos franciscanos, menos um (escolhido por eles a dedo), eram de uma formação admirável. Todos eram poliglotas, incluídos os brasileiros. Havia alguns que eram alemães e também eles todos eram poliglotas. Não me lembro de um só de meus professores que dominasse menos que três ou quatro línguas. Isto nos colocava a todos num verdadeiro ambiente internacional. Era familiar, para nós, ver grupos de alunos saírem a piquenique falando somente francês ou somente inglês ou somente alemão, para exercitar a língua o dia todo. A literatura de diferentes línguas estava aí, o tempo todo à mão, tanto na biblioteca central (dos professores), quanto nas 3 bibliotecas setoriais (dos alunos). Eram frequentes as noitadas (literomusicais: assim as chamávamos), dedicadas à determinada língua estrangeira (alemã, latina, grega, francesa, inglesa, principalmente estas) em que se declamavam poesias, cantavam-se corais, encenavam-se peças teatrais etc., em uma língua estrangeira determinada. $\mathrm{O}$ mundo, assim, ficava bem mais "ancho" que o mundinho de onde provínhamos. Mais:

Recebíamos em Agudos pequenos grupos de colegas alemães, de belgas, de sul-americanos de vários países e aí vinham seminaristas de Goiânia (GO), cuja formação havia sido dada, até então, por frades norte-americanos (bons de basquete, que só!). 
O Seminário de Agudos é uma imensa construção de puro estilo neocolonial. A frente e os fundos medem $310 \mathrm{~m}$ e as laterais medem 200 m. Essa área toda é atravessada por quatro alas, que correm da frente para os fundos e por quatro que correm de lateral a lateral, com jardins internos, fontes e árvores ornamentais. Há um auditório chamado de "Salão Nobre", com a melhor acústica de todo o interior paulista, com poço para orquestra sinfônica e um auditório em declive. O salão é ornamentado com pinturas de artistas famosos. Contíguas ao auditório há saletas de pianos em um dos pisos e saletas com harmônios (órgãos) no piso de cima. Ligadas a estas saletas, reciprocamente, no andar de cima está a sala de orquestra e no térreo a sala da banda sinfônica de instrumentos brancos. Todos os ambientes são protegidos com paredes acústicas feitas nos melhores padrões técnicos da época da construção. Para o esporte havia piscina olímpica, dois campos de futebol gramados de tamanho oficial, várias canchas de basquete, de vôlei, de futebol de salão etc. Praticava-se também o atletismo, com múltiplas modalidades.

Tivemos, em Agudos, professores licenciados e mestres, incluído um Doutor em Física (com doutorado realizado nos Estados Unidos), Frei Onésimo Dreyer a quem homenageio, no final de meu livro A origem normativa da prática educacional.

Findos os estudos do que denominamos, hoje, ensino médio, segui para o noviciado, em Rodeio (SC). Não sem antes realizar uma solene formatura em que o coral que eu havia fundado e regido desde terceiro ano do ginásio ( $7^{\mathrm{a}}$ série do ensino fundamental) apresentou, no salão nobre, Glória, da Missa da Criação de Mozart, acompanhado ao piano por meu colega Cláudio Bennemann, com quem tantas vezes me apresentara tocando em concertos de violino e piano. Aliás, nossa turma mantinha, desde o ginásio, um coral a quatro vozes iguais, uma pequena orquestra de câmera e uma revista (então datilografada e ilustrada por nossos próprios artistas, ora em óleo, ora em guache etc.). Tenho que ressaltar, ainda, que em Agudos aprendi a tocar violino e integrava a orquestra local. Ressalto sempre que em nossa formação de seminário sempre estávamos ante o rigor científico, mas, também, em atividades estéticas, literárias e desportivas de toda sorte, com excelentes condições para todas essas práticas.

O noviciado foi um dos melhores anos de minha vida. Vivi aí uma mais que histórica virada de página na Igreja, pois justamente em 1965 fazia o noviciado, ano em que terminou o Concílio Vaticano II. Pude vivenciar 3 meses de um noviciado tal como se realizava na Alemanha do século XIX e os demais meses, um noviciado pautado pelo Concílio Vaticano II, de profundas renovações. Antes disto, vivenciei, por exemplo, o ofício divino da meia-noite, um costume milenar. Foi um ano de muita reflexão, de muito debate, de muita renovação e, para mim, de muitíssima leitura. Frei Basílio Prim, que sucedeu Frei Hugolino Becker, foi o que 
nos ajudou a fazer a virada histórica de uma Igreja antiga para uma Igreja renovada, com uma sabedoria e bom senso, liberdade que muitas vezes não encontrei mais nem no "mundo do século". Em suas conferências diárias, sempre abertas ao debate, dizia: "Aqui tudo, absolutamente tudo pode ser discutido. Não há nenhum tema ou assunto proibido. Mas... com argumento". Foi um mestre para o resto de minha vida. O reencontrei, antes de seu falecimento, em Blumenau, durante meu Mestrado em Educação: Ensino Superior, onde prosseguimos em profundas discussões.

Curitiba (PR): curso de Filosofia (1966-1867). Ah! Curitiba! Uma cidade intensamente cultural. Tive aí professores renomados como Frei Raimundo Vier, um dos grandes nomes mundiais, quando se trata de estudos medievais em torno de Duns Scotus. O ambiente acadêmico era internacional. A Filosofia era ministrada em dois anos, mas com carga horária muito grande. A pesquisa através de literatura internacional já era bastante naturalizada, para nós. No segundo ano (último da Filosofia), me propus a não compulsar nenhuma literatura em língua portuguesa para todos os trabalhos acadêmicos a serem realizados. Consegui este intento. E valeu a pena. Senti-me transido por um nobre orgulho quando, em certa feita, Frei Raimundo me mandou representá-lo num encontro de cientistas, em Curitiba. O tema girava em torno de Pierre Teilhard de Chardin, o então mais que celebrado paleontólogo jesuíta. E por falar, ainda, de Frei Raimundo Vier, recebi dele o exemplo máximo da abertura intelectual que nunca mais me abandonou:

Frei Raimundo, meu principal professor de Filosofia e Diretor dos Estudos do Instituto Franciscano de Filosofia, certo dia me abordou e disse:

Ireno, percebo seu grande interesse pela filosofia contemporânea. Eu sou um medievalista. Trato da filosofia até a Modernidade, com vocês e, depois, não sigo adiante, dado o tempo e a carga horária disponível. Assim, como administro recursos financeiros para manter o Instituto, sobretudo no que diz respeito à biblioteca, vou te repassar um valor. Com ele você pode adquirir as obras que julgar interessantes. Estude-as e depois venha discuti-las comigo para que eu também aprenda um pouco de filosofia contemporânea. A seguir, quando deixar de utilizar as obras, entregue-as à biblioteca.

O que será que um seminarista filósofo como eu andava mesmo estudando?

De fato, nas provas acadêmicas eu sempre dava um jeito de incluir os meus preferidos pensadores contemporâneos. Eu andava deslumbrado com a filosofia e as abordagens culturais de Jean-Paul Sartre, Simone de Beauvoir, Albert Camus, André Gide, Malraux etc. E esta "descoberta" havia se dado quando, no seminário de Agudos (SP), numa 
manhã ainda de férias do mês de fevereiro de 1961, fazendo jardinagem ou, então, usando uma linguagem mais direta: capinando no imenso jardim (eram 10 alqueires ajardinados), sem pressa, e muito menos pressionado, eu ouvia atentamente uma conversa de Frei Armindo de Oliveira (o mesmo que me "pescara", na minha escolinha Belo Horizonte do Bem-te-vi), que era, então, nosso Padre Diretor, com um colega do $10^{\circ}$ ano do ensino clássico (eu estava no $4 .^{\circ}$ ano do ginásio) sobre uma obra recém-publicada, com o título A literatura do século XX e o cristianismo (não lembro mais o nome do autor). A obra tratava justamente do pensamento destes e de outros autores contemporâneos. E todos sabem que o Existencialismo estava no auge, na década de 60, sobretudo entre a juventude do mundo inteiro. Onde quer que Sartre e Simone aparecessem para proferir palestras, acorriam multidões para ouvi-los. E a conversa de Frei Armindo com Dário Deschamps, meu colega (que seria meu professor no Mestrado em Educação, em Blumenau, tantos anos depois) me deixou absorto, quase basbaque. Como podia, um colega meu, um ano adiantado em relação a mim, manter conversa tão elevada e sábia com um professor? Juro que aquela conversa foi uma explosão de vontade de conhecimento dentro de mim. Virou sonho alçar o voo do conhecimento. E acho que alcei. Nessas mesmas férias eu já havia comprado meus primeiros dois livros de filosofia. Um superclássico (Jacques Maritain, bem conservador) e outro do norte-americano Fulton Sheen (fico sabendo neste instante que ele foi beatificado por Bento XVI, por suas grandes virtudes).

Bem, o Ireno que reprovara por duas vezes, um autêntico fracasso escolar, começava arribar. Foi no último ano do ginásio (corresponde à $8^{\mathrm{a}}$ série do ensino fundamental), que fui me tornando um projeto de intelectual. No Latim, que reprovara uma vez, comecei a me destacar como um dos estudantes da turma que fazia as melhores traduções e era nomeado como líder de grupos de estudos. Sim! Conto isto sem pudor, para que todos saibam que o tema FRACASSO ESCOLAR se tornou, para mim, uma expressão de achaque. Uma expressão que só serve para produzir fracassados. Uma expressão que deve sempre ser tomada como ofensiva. É buling, sim senhor! A reconciliação com a Matemática demorou um pouco mais. Juro a todos os que me leem, para que colham ânimo aqui, que eu julgava, desde minha entrada em Luzerna, em 1954, até o ano de 1963 (segundo ano do clássico), que eu jamais aprenderia Matemática. Que a Matemática era para os meus colegas sabichões em Matemática, como o José Tondo e mais uns poucos. Eu? Nunca! Era assim que pensava, até que, pelo final de 1963, no penúltimo ano do ensino clássico comecei a pensar diferente. "Por que eu não?” Ora! Estaria escrito em minha testa que "Eu não?!" E comecei a me organizar bem. As anotações de Matemática feitas quase com asco, começaram a ser cuidadosas, feitas com gosto. Mas vou logo ao ponto: 
$\mathrm{Na}$ época, desde o ensino primário, enfrentávamos as provas trimestrais escritas e no final do ano, as provas escritas gerais e bancas de provas orais, se não alcançássemos média 7 , no mínimo.

Pois bem. No final de 1964 vieram as provas finais. Eu já não temia mais o Latim, mas ainda era um neófito em Matemática. Fiz provas escritas. E, dependendo da média geral, não faria as provas orais (se igual ou acima de 7).

Como disse, o Seminário de Agudos era uma estrutura imensa. Seus corredores eram agigantados, todos abertos para o exterior, em arcos romanos. Um trator de pneus entrava carregado de terra para os jardins internos e sobrava espaço em ambos os lados. Caminhar neles era sempre uma sensação de grandeza, de amplidão, de espaço livre. Dava uma boa sensação de liberdade. Pois bem. Foi uns dias após as provas escritas de Matemática de 1964 que vi, ao longe, vindo em minha direção, o professor de Matemática, Frei Lucínio Wzorek (se errei a grafia... desculpem). Era um homem que eu odiara tanto quanto a Matemática, mas que no $3 .^{\circ}$ ano do clássico descobrira que era uma alma extraordinariamente alegre, aberta, afável e um sábio para quem a Matemática era um divertido jogo, que publicava pesquisas astronômicas junto com Frei Onésimo Dreyer, o doutor em Física. Fiquei um tanto apreensivo. Ele poderia vir a falar coisas desagradáveis das provas de Matemática. Mas, quando chegou a uma distância menor, levantou os dois braços (estava de hábito franciscano, como de costume), esboçou uma expressão de muito entusiasmo e exclamou: "Ireno, seu danado! Você quase me tira 10 na prova final de Matemática!"

O resto seria dispensável dizer. Mas eu vencera mais uma longa batalha para sustentar minha rejeição à expressão: FRACASSO ESCOLAR. Definitivamente, eu não era um fracasso, atributo "evidente" de quem reprovara por duas vezes. E mais: como era de costume em todos os estudos realizados no seminário menor (fundamental e médio), os alunos recebiam, cada um em sua turma, um ordinal classificatório do $1 .^{\circ}$ ao último lugar. Por muitas vezes, até o terceiro ano do ginásio eu ocupei o antepenúltimo lugar, o 29. ${ }^{\circ}$ entre 35 , e assim por diante. Posso estar enganado, mas até o final de meu curso de doutoramento, penso que não ocupei mais nem o $2 .^{\circ}$ lugar, desde o noviciado. Relato isto, não por vaidade, mas para alertar a todos que não existe fracasso escolar. Para dizer àqueles que, como eu, se sentirem a figura do fracasso escolar saibam, que lá dentro de si mesmos (e nunca nos outros: no professor...) há uma faísca que precisa ser acesa para explodir o conhecimento. Se cada um de nós não fizer um profundo e radical ato de fé em si mesmo, de nada há de valer qualquer outro ato de fé. Trata-se de um ato de amor para conosco mesmos. Um ato que nós mesmos (por vezes com perversas ajudas), negamos a nós e depositamos nos "outros". Fiz isto por anos a fio. O susto da primeira reprovação me tornou um menino desconfiado de mim mesmo. Faltou algum acontecimento 
que me levantasse, até começar a encontrar, não um só, mas uma série acontecimentos, a partir da conversa de Frei Armindo com o Dário, meu colega, que incendiaram minha força, que elevaram a labareda da vontade de saber e da autoconfiança.

Bem, o curso de Filosofia foi uma festa, para mim. Já havia espantado todos os meus fantasmas que me insuflavam a ideia maligna do "fracasso escolar". O curso de Teologia foi outra festa, talvez menor que a da Filosofia, pois eu me enamorara desta e fizera com ela um casamento indissolúvel. Sou-lhe fiel até hoje. Mas a Teologia também foi um luxo. Este curso, o realizei em Petrópolis (RJ). Lá a Filosofia foi juntada com a Teologia e por isto, pude ainda frequentar algumas disciplinas da Filosofia. Cheguei em Petrópolis para cursar a Teologia (com Filosofia também), em 1968. Justo naquele ano voltavam jovens professores que haviam cursado o doutorado na Europa: Frei Leonardo Boff (doutor em Teologia e em Filosofia); Frei Arcângelo Buzzi (doutor em Sociologia por Louvain); Frei Fábio Panini, doutor em Direito Canônico e formado em Direito Civil. Frei Hermógenes Harada, que cursara 10 anos junto a Martin Heidegger, na Alemanha. Não defendeu tese porque não fazia, de forma alguma, seu estilo, que em tudo se afastou das formalidades desnecessárias. Harada foi tão brilhante aluno de Heidegger, que depois o convidou de volta para a Alemanha para trabalhar com ele, salvo engano meu, na publicação da obra crítica de Raimundo Lúlio. Que timaço de professores!

Enfim, em Petrópolis, morando sob o mesmo teto da Editora Vozes, que se tornou uma respeitável editora (é a mais antiga em atividade, no Brasil), a vida acadêmica ganhou ainda mais internacionalidade. Nossos professores, ao menos boa parte deles, era gente do mundo. Chegavam à biblioteca dos estudantes todos os dias, dezenas e dezenas de livros e dezenas mais dezenas de números de revistas vindas de todo o planeta, pois a Vozes permutava suas revistas e livros com editoras de muitos países. Assim, podíamos estar sintonizados com o que acontecia em muitas áreas do saber em todas as partes do mundo, através das mais diversas línguas estrangeiras ou, é óbvio, também em português.

Em Petrópolis (1967-1970), minha turma de estudantes talvez tenha sido a primeira no país em que, alguns de nós, optamos por viver fora do convento franciscano, num bairro popular (Bairro Castrioto), trabalhando meio expediente e estudando no outro. O grupo foi constituído por mim, por meu irmão Benjamim, pelo colega belga Franz Missen, pelo meu colega pianista Cláudio Bennemann e pelo pároco da Paróquia Sagrado Coração de Jesus, Frei Bruno Fuchs, alemão, o mais experiente de nós, ainda bastante jovem. Permanecemos por um ano nesta condição. Eu trabalhei um semestre na tradução da obra Inteligência no universo, publicada pela Editora Vozes. Assim, cada 
qual tinha seu emprego. Foi uma experiência pioneira que gerou novas experiências, que se perpetuaram até hoje.

Ainda em Petrópolis, durante o curso de Teologia, o Cláudio e eu trabalhamos na produção da revista Bibliografia Classificada. Nosso trabalho era resenhar, em poucas linhas, todos os livros que iam chegando, todos os dias, pelas permutas que a Editora Vozes fazia pelo mundo afora. Foi, para nós estudantes, uma grande experiência no desenvolvimento da capacidade de síntese. Produzíamos a referência bibliográfica e um resumo brevíssimo (algumas linhas), de cada obra. Tenho fotos do Cláudio e eu com pilhas de livros sobre a respectiva mesa de trabalho. Tínhamos que "devorar" pilhas e pilhas de livros, reduzindo o conteúdo de cada um a um único parágrafo.

Foi ainda em Petrópolis que ouvi uma conversa de corredor, em que estudantes da turma que nos sucedia, em que comentavam que havia uma lei federal que permitia fazer a convalidação de nossos estudos de Filosofia que, à época que cursamos, não eram reconhecidos pelo Ministério da Educação.

Parti imediatamente atrás das informações precisas. Arranjei todos os documentos de cada um dos estudantes da minha turma. Alguns (quase todos) não tinham sequer identidade. Recebi autorização para ir a São Paulo, no Provincialado Franciscano, onde estavam os arquivos com as informações sobre nossos estudos de Filosofia, para redigir os históricos escolares de tudo o que havíamos cursado. Assim, seguindo uma orientação dos superiores, além de cursar um semestre para completar o currículo da Licenciatura em Filosofia da Universidade Católica de Petrópolis (UCP), cada um poderia também matricular-se em qualquer outro curso. Uns cursaram Direito, outros Economia etc. Eu optei por medicina, mas este curso não foi permitido. Minha sorte tem sido gostar muito da Filosofia, que preencheu meus sonhos, ao menos em grande parte.

Findo o terceiro ano de Teologia, na Província Franciscana a que pertenci, ocorria a ordenação sacerdotal. Desta maneira, em janeiro de 1971 fui ordenado padre franciscano, juntamente com meu irmão Benjamim, com quem fiz todos os estudos desde o primário.

Penso que para nossa felicidade (minha e do Benjamim: ele continua frade até hoje), nunca fizemos do contingente algo absoluto. Sempre tivemos muito claramente, para nós, que o contingente é deste mundo. E que o transcendental metafísico... bem este pertence a outra ordem de coisas e que é o contingente que está a nosso alcance. Isto nunca nos tornou dogmáticos. Isto deixou sempre nossa mente aberta, não nos torturando com aquilo que não podemos mudar, com aquilo que não conseguimos controlar. Talvez é por isto que a obra de Sartre, ao invés de fazer de mim um ateu, ajudou-me a me tornar mais místico-reflexivo. Talvez seja por isto que $A$ origem das espécies de Darwin, que li com tanto gosto, contribuiu como um notável incremento na minha visão ecológico-mística do 
mundo (mística, no sentido de me ver diante do inefável, imenso, inabarcável mesmo para a ciência e para a razão). Certamente é por isto mesmo que a leitura da obra inteira de Nietzsche me faz meditar sobre a profundeza de nossa humanidade, de nossas virtudes e de nossas fraquezas. E, certamente é por isto que não me assusta o fato de a moral ter gênese. Penso que a formação como a recebi, mas principalmente como eu mesmo a levei adiante, com a ajuda de tantos que me inspiraram a pensar, me deu o privilégio de, sendo um ancião de 73 anos, sentir pulsar com toda a força o coração da criança que nunca deixei de ser. Assim, o pensamento pós-moderno/pós-estruturalista/hipermoderno/ moderno líquido, a complexidade, a auto-organização e o caos parecem corresponder (ressoar, fazer eco, rissonare per simpatia, como dizem os italianos) ao que me tornei no mundo e com ele. Penso que tudo o que me aconteceu (a vida como acontecimento), me desvinculou de qualquer necessidade de dogmas, de qualquer certeza absoluta e cega, de qualquer rótulo religioso, para ser profundamente religioso sem fôrmas/fórmulas nem rótulos demarcatórios que me separam indefectivelmente dos outros, numa gostosa lógica da diferença. Que espanto verificar que não há duas folhas só iguais em todo o planeta Terra, duas íris dos olhos iguais, duas digitais iguais no passado, no presente e no futuro. Que fantástico!

Findos os estudos de Teologia, me esperava a primeira transferência. E foi para Pato Branco (PR) que fui designado.

Em Pato Branco encontrei uma comunidade franciscana muito fraterna. Por outro lado, encontrei uma pastoral bem tradicional, apesar de a paróquia local dispor, então, de duas rádios e de estar em processo de instalação de um canal de televisão, como de fato posteriormente instalou. Minha permanência no sacerdócio não perdurou muito. O meu irmão Benjamim, a posteriori lembrou como eu fui rapidamente me apagando, perdendo o entusiasmo paroquial que, de início, foi muito empolgante. Senti que EU (não meus confrades), me encontrava no lugar errado, apesar de tantos anos de formação de seminário (16 ao todo). Assim, assumi por mim, sem o menor conflito, sem a menor contenda, que mudaria de rumo minha vida. Afinal, nisto também vai muito de uma atitude ante o contingente que não absolutiza nada porque, neste mundo, tudo é contingente. A formação que recebera, em todas as etapas, me habilitaria a ocupar diferentes espaços com a mesma desenvoltura. Recebera uma formação magnífica, variada: formação religiosa, formação científica, formação social, enfim, que formação! Uma formação muito aberta.

Quando o bispo de Palmas (PR), diocese a que pertence a paróquia S. Pedro Apóstolo, de Pato Branco, soube que eu me desligaria da Ordem Franciscana, veio me procurar com uma bela proposta. Depois de dizer do respeito que tinha pela minha decisão convidou-me para integrar o corpo docente da então FECIPAL, que era uma instituição 
de ensino superior administrada pela diocese de Palmas. Propiciaria-me uma pós-graduação lato sensu e me conferiria duas disciplinas para ministrar. E enquanto não tivesse onde morar (ele sabia que sairia da Ordem com uma mala de roupas e com alguns livros, somente.. Pediu-me, ainda, para que ministrasse um curso de teologia para o clero diocesano, antes de sair de Pato Branco. Agradeci e recusei a pós-graduação, as atividades na FECIPAL e a hospedagem e elaborei um curso de teologia para o clero. No dia do curso chovia copiosamente. E como não havia asfalto na cidade em que se realizaria o encontro do clero, pus-me a caminho, mas logo atolei o fusca na lama, tendo que retornar, sob o risco ficar a meio caminho.

Tomada a decisão de me desligar da Ordem Franciscana e de deixar as atividades sacerdotais, encaminhei, através de meus superiores, o pedido de dispensa de Roma. O Papa de então concedia as dispensas sem causar dificuldades nem transtorno aos solicitantes. Assim, em 6 meses chegou minha dispensa de Roma.

No semestre em que aguardei a dispensa de Roma busquei um meio de sobrevivência. Mesmo tendo apenas um ano de experiência na docência do ensino fundamental e médio, não tive dúvida que meu caminho seria o ensino superior. Realizei uma viagem pelo norte do Paraná, onde já havia algumas instituições recém-instaladas de ensino superior. A década de 1970 foi a década de interiorização do ensino superior no Brasil. Por lá, pareceu-me tudo muito "privado", ou seja, eram instituições empresariais. Sabia que em Cascavel (PR) havia uma instituição de ensino superior municipal recém-instalada, mas julgava que por ser uma cidade já bem desenvolvida, um iniciante como eu não encontraria espaço aí. Que belo engano!

$\mathrm{Na}$ viagem de reconhecimento em busca de trabalho no ensino superior levei comigo meu amigo e colega Cláudio Bennemann, o pianista, que exercia seu trabalho pastoral em Coronel Freitas (SC). Depois de um dia de peregrinação, retornamos e, a meio caminho, já à hora de jantar, paramos num restaurante para este fim. Aí eu disse ao Cláudio: "Amigo velho, vou mesmo ter que pedir a bênção de D. Agostinho, bispo de Palmas para arranjar trabalho. Penso que não me resta muito além de aceitar o convite dele. Assim, vejo-me na contingência de passar por Cascavel e sondar algo por lá".

Cascavel (PR), que estava fora de minhas cogitações acabara de entrar para elas: seguiríamos, depois do jantar, rumo a Cascavel. Na entrada daquela cidade desabou tamanho temporal que mal se viam, à distância, as luzes. Assim, orientados pelas luminárias da cidade, fomos andando e chegamos ao centro, na Avenida Brasil. Aí, escolhemos um bom hotel e nos hospedamos. Era sexta-feira.

Na manhã de sábado, ao descermos para a garagem para apanhar o automóvel, vi um cidadão bem vestido, de gravata, passando à frente da porta. Não sabia, então, que se tratava do prefeito da cidade e presidente da 
fundação que mantinha minha primeira chance de trabalho, a FECIVEL. Abordei-o e lhe perguntei se sabia onde ficava a residência do diretor da Faculdade de Educação, Ciências e Letras de Cascavel (FECIVEL). Como eu sabia que o diretor era também juiz em Cascavel, perguntei também ao transeunte, que mostrou conhecer bem o endereço do diretor, se este me receberia, num sábado de manhã. A resposta foi afirmativa e que se tratava de pessoa muito educada e comunicativa. A residência do diretor distava a umas duas quadras apenas e ficava bem no centro da cidade. Fui amavelmente recebido. Fui logo apresentando meu currículo e externando a vontade de ser convidado a lecionar na FECIVEL. Informei-o de que deixaria a Ordem franciscana e tudo mais e se isto não se constituiria impedimento, no seu modo de perceber o assunto (fui descobrir mais tarde que quando advogado pobre, em Pato Branco, Frei Policarpo, diretor das rádios locais lhe emprestara uma casa para morar, a custo zero). O diretor e juiz foi enfático em dizer que era de pessoas com essa boa formação que a FECIVEL precisava para seus quadros. Não teria uma disciplina disponível, no momento, para me oferecer, mas tão logo aparecesse uma oportunidade me comunicaria.

Passados 3 meses, recebi um telefonema da Secretária da FECIVEL, me convidando para lecionar Estatística Aplicada à Educação. Acedi ao convite e, durante um semestre, ia e vinha entre Pato Branco e Cascavel. Ministrava duas aulas na quinta-feira e duas na sexta-feira. Findo o semestre, ocorreu a vinda da dispensa de Roma e me mudei para Cascavel. Lecionei lá, primeiro a disciplina mencionada e depois também Medidas Educacionais e Psicologia da Educação. Isto ocorreu no segundo semestre de 1993 até abril de 1997, quando, atraído pelos programas agrícolas do Governo Federal que tinham por objetivo ocupar a Amazônia, pedi rescisão de meu contrato com a FECIVEL e me mudei com a família para o Território Federal de Rondônia.

Enquanto morava em Cascavel, em 1974, eu namorava Maria Lourdes Warcken, estudante universitária de Guarapuava. Ô namoro difícil! (Mas gostoso!) Com pouco dinheiro, viajar a quase $300 \mathrm{~km}$ para namorar não foi fácil. Ia a Guarapuava a cada 15 dias ver a Maria Lourdes. Assim, para contornar a dificuldade, resolvemos nos casar no início de 1975. E, de fato, casamos em fevereiro desse ano. Em novembro nasceu nosso primeiro filho, o Ivan (engenheiro civil) e a Maria Lourdes, que havia arranjado emprego na Telecomunicações do Paraná, (TELEPAR), renunciou à vaga para cuidar da gestação e do neném, o Ivan, que nasceu no dia 11 de novembro de 1975.

Em abril de 1977, ao nos mudarmos para Rondônia, a Maria Lourdes estava gestante de 7 meses de nosso segundo filho, o Ivânio (advogado e bancário).

A história de nossos 10 anos vividos em Rondônia deverá render um alentado volume que ainda pretendo escrever, quando parar definitivamente de trabalhar como 
assalariado. Por isto, vou ser breve. Posso adiantar que foi uma verdadeira epopeia ir morar em Rondônia, em abril de 1977 e ter ficado por lá até 1987. Em 1980 nasceu nossa filha Mônica (Educadora Física). O time ficou completo.

O sonho de quem se mudou para Rondônia, naquela época, era a terra para o plantio planejado e financiado de cacau, seringueira e café. Quanto ao cacau, a novela da Globo, Renascer, mostrou ter redundado em um grande fracasso com o massivo ataque da doença popularmente denominada vassoura de bruxa, um fungo devastador para os cacaueiros. As duas áreas que plantei foram profundamente afetadas.

Durante os primeiros meses que residimos em Rondônia, após ter recebido a terra que o INCRA distribuía a custo quase zero (pagava-se apenas a topografia, com valor simbólico e facilitadíssimo), nos mudamos da cidade de Ariquemes (que fica no centro de Rondônia), para a capital, Porto Velho onde, na Secretaria de Educação, administrei o Núcleo da Universidade Federal do Pará, em Porto Velho e o Núcleo da Universidade Federal do Acre, em Guajará Mirim, os dois únicos municípios do então Território Federal de Rondônia.

Nesses poucos meses fui incumbido de elaborar projeto de implantação de núcleos da Universidade Federal do Pará em outros quatro dos recém-criados 7 novos municípios do Território. Terminado este trabalho (exitoso), rescindi meu contrato com o Governo Federal e me mudei para Ariquemes, pois essa era uma exigência do INCRA para que tivéssemos direito à terra distribuída por esse órgão de reforma agrária. Como todos que ali aportavam para residir, eu também recebi a custo zero um lote urbano na recém-criada cidade de Ariquemes (planejada pelo Governo Federal) e instalada no meio da Floresta Amazônica. Imaginem-se as dificuldades de toda ordem e tendo por protagonista eminente, a malária.

Em 1978 plantei minha primeira área de cacau (15 hectares), com financiamento do Banco do Brasil e orientação técnica, desde o projeto, realizada pela Comissão Executiva do Plano da Lavoura Cacaueira (CEPLAC), órgão federal específico para orientar a implantação e condução da lavoura cacaueira, tanto na Bahia como, então, também em Rondônia. Tudo correu bem até o início da produção precoce do cacau. Mas, tão logo o cacau começou a produzir, concomitante, a vassoura de bruxa, esse terrível fungo, começou a atacar a lavoura e a dizimá-la.

Destaco que, em Rondônia, nunca cessei de exercer a profissão de educador. Pouco tempo depois de retornar a Ariquemes, implantada a primeira lavoura de cacau, fui contratado pela prefeitura local. Primeiro assumi como Diretor do Departamento de Educação e depois como Secretário de Educação e Cultura. Poucos meses depois, todos os servidores das novas prefeituras foram transferidos para a folha de pagamento do Governo Federal. Assim permaneci até 1987, quando eu e minha família resolvemos retornar 
ao Sul. Não fazia mais muito sentido enfrentar as malárias e um clima muito hostil, além da violência que se iniciava por lá, com a proibição do garimpo manual do minério de cassiterita (onde estão as maiores jazidas do mundo desse minério do estanho). Começava a intensificar-se também o narcotráfico. Enfim, nossa decisão foi por retornar para o Sul. Tenho que dizer que Ariquemes recebeu o apelido um tanto pomposo de Atenas de Rondônia pela qualidade de sua educação, pelo quadro de professores urbanos (todos lotados de conformidade com sua formação) e pelo notável desenvolvimento das artes e da cultura em geral.

Em 1987 alugamos uma casa em Canela (RS), por 6 meses. Não sabíamos, ainda, o que faríamos lá. E, enquanto aguardávamos nossa distribuição para Porto Alegre (para a Delegacia do MEC do Rio Grande do Sul), surgiu o convite para que eu integrasse uma equipe para a elaboração do projeto que resultou na criação da Universidade do Oeste de Santa Catarina (UNOESC), que juntava numa única universidade as Fundações Educacionais denominadas Fundação do Desenvolvimento do Oeste (FUNDESTE), de Chapecó (SC), a Fundação de Joaçaba (SC), mais a de Videira (SC), com os campi de São Miguel do Oeste (SC) e de Xanderê (SC), ligados à Fundação do Desenvolvimento do Oeste (FUNDESTE). A isto se deve minha mudança para Chapecó, em agosto de 1990.

Antes mesmo de concluir o projeto de criação da UNOESC, ingressei na primeira turma do Mestrado em Educação: Ensino Superior da Universidade Regional de Blumenau (FURB). Concluí em 1994, e fiz minha defesa de dissertação em fevereiro de 1995. E logo em setembro de 1996 ingressei no curso de Doutorado em Educação da Universidade Federal do Rio Grande do Sul (UFRGS). Defendi minha tese em 30 de agosto de 2000.

Lutei durante 12 anos com uma equipe que foi se fazendo e refazendo, até conseguirmos a aprovação pela CAPES de nosso Mestrado em Educação. Já está prestes a dar ingresso à quarta turma, no próximo semestre. Só nós que nos envolvemos no projeto sabemos o quanto lutamos para que isto fosse possível.

Com poucos interregnos, sou professor universitário há 42 anos e pai de família há 40 anos. Uma de minhas melhores descobertas, no mundo secular, depois da vida religiosa franciscana foi dar-me conta que existe muito mais daquilo que geralmente se chama de santidade, de virtude, de bondade, de doação, de generosidade, de fraternidade do que antes imaginava. Quanta virtude encontrei, virtude sem rótulo, sem credo, sem templos, sem igrejas, encontrei e continuo encontrando no mundo secular. Outra constatação sublime foi certificar-me, em 42 anos de vida profissional, que tudo o que os franciscanos me ensinaram, desde o primário até o final de um segundo curso superior não confronta com as necessidades/demandas intelectuais, sociais, técnicas e profissionais que o mundo exigiu de mim no século. Que formação recebi! E meu pai e minha mãe 
não se cansavam de dizer: "Valtri no me ghecostàniente" ("Vocês não me custaram nada", em italiano, referindo-se a mim e ao meu irmão Benjamim que sempre estudou, no seminário menor e maior, comigo).

Da vida a dois e depois a cinco, em família, assevero que, com todas as dificuldades que passei na vida (e não foram poucas), tudo foi melhorando e não quereria morrer nunca, nem quereria ter melhor companhia que a Maria Lourdes, que meus filhos e os cinco netos que possuo. Quanto mais convivo melhor a convivência. E a universidade tem sido, ressalvados os normais problemas, um lugar privilegiado, muito fraterno, muito além do que pudera ter imaginado, antes de entrar nele. Se não fosse isto, certamente não teria prolongado por 42 anos minha permanência neste meio, ainda sem data para encerrar a atividade. Por outro lado, apesar de meus bons 74 anos, o gurizão que me levou para a universidade ainda está bem vivo, bem esperto. No dia que eu mesmo constatar que ele "envelheceu" mesmo, que ficou tristinho, que ficou desacreditado do mundo e dos homens, bem como das mulheres, ninguém precisa me mandar: eu mesmo irei andando e sairei de cena. Por ora, ainda sou muito feliz por aqui. E enquanto alguém não me disser que está infeliz com minha presença, companheiros de tantos anos e companheiros da última hora, vamos andando que há ainda muito chão e muito a fazer. Vejo a nova geração de professores como muito digna e preparada para substituir a quem o tempo determinar que seja substituído. Sinto confiança na geração jovem de professores. E parece que eles ainda confiam em mim. Sou grato pela vida que vivi e por aquela que ainda me resta (penso que não será tão pouca, não). 